\title{
Thromboembolic tendency (TE) in IBD (inflammatory bowel disease) patients
}

\author{
A Canero*, L Goffredi, M Apperti \\ From de Senectute: Age and Health Forum \\ Catanzaro, Italy. 5-7 December 2009
}

\section{Background}

The incidence of TE events in IBD patients is higher than in population control [1,2].

The main reason for this, is the hypercoaugulable state $[3,4]$.

Our aim was to detect serum markers related to TE, that can assume preventing and prognostic meanings.

\section{Materials and methods}

We performed a 3 year study on 71 patients with IBD, evaluating hypercoaugulability, and then we compared the results with 71 patients non IBD group control.

We also investigated patients of both groups concerning TE events occurred already.

\section{Results}

In IBD group we found out that 16 patients (22.5\%) had a history of TE versus $>1 \%$ of group control.

19 of them, already had knowledge of their previous hypercoaugulating condition.

$48(67 \%)$ had increased markers value versus less then $6 \%$ detected in group control.

In IBD group $43 \%, 20 \%$ and $4.2 \%$ had respectively 1 , 1-3 or $>3$ markers higher levels then normal range.

Among the markers investigated, we detected increased levels of plated in 33\%, homocysteine in $26.7 \%$, d-dimero $25.3 \%$, c3 in $15.4 \%$, apcr in $5.6 \%$.

\section{Conclusions}

From our study we detected a higher incidence of TE events, and hypercoaugulating status in IBD group. In our previous investigations, plated, homocysteine, d-dimero, c3, and apcr, seemed to be the TE markers with higher sensibility.

Dipartimento di Scienze Chirurgiche e Anestesiologiche, Seconda Università degli Studi di Napoli Italy Centro Interuniversitario di Ricerca e Formazione in Flebologia, Italy
It seems reasonable, according our experience, to propose a new TE risk score index for IBD patients:

low, mild and high risk respectively for patients with $1,1-3$ and $>3$ markers with higher serum levels then normal range.

Published: 19 May 2010

\section{References}

1. FarroKhyar F, Jan Irvine E, Swarbrick ET: A critical review of epidemiological studies in inflammatory bowel disease. Scand. J Gastroenterol 2001, 1:2-15.

2. Bernstein CN, Wajda A, Blanchard JF: The incidence of arterial thromboembolic diseases in inflammatory bowel disease: a populationbased study. Clin Gastroenterol Hepatol 2008, 6:41-45.

3. Miehsler W, Reinisch W, Valic E, Osterode W, Tillinger W, Feichtenschlager T, Grisak J, Machold K, Scholz S, Vogelsang H, Novacek G: Is IBD an independent risk factor for thromboembolism. Gut 2004, 53:542-548.

4. Webberley MJ, Hart MT, Melikian V: Thromboembolism in inflammatory bowel disease: role of platelets. Gut 1993, 34(z):247-251.

doi:10.1186/1471-2318-10-S1-A51

Cite this article as: Canero et al:: Thromboembolic tendency (TE) in IBD (inflammatory bowel disease) patients. BMC Geriatrics 2010 10(Suppl 1):A51.
Submit your next manuscript to BioMed Central and take full advantage of:

- Convenient online submission

- Thorough peer review

- No space constraints or color figure charges

- Immediate publication on acceptance

- Inclusion in PubMed, CAS, Scopus and Google Scholar

- Research which is freely available for redistribution

Submit your manuscript at www.biomedcentral.com/submit
C Biomed Central 